\title{
Organizational capacity, motivation, or intervention capacity?: Are these affects online teaching readiness and need satisfaction of students
}

\author{
Ananta Kumar Jena ${ }^{1}$, Munmi Barman², Jaishree Devi ${ }^{3}$, Satarupa Bhattacharjee ${ }^{4}$, Sabina Yeasmin \\ Barbhuiya ${ }^{5}$ \\ 1,2,3,4,5 Department of Education, Assam University, Silchar-788011, Assam, India \\ E-mail:1 akjenaaus@gmail.com
}

\begin{abstract}
In this pandemic situation, educational institutions are trying to co-operate students in continuing learning without face-to-face interaction. Teachers have online teaching readiness with their own organizational capacities, motivation, and interactive capacities and use online teaching strategies to satisfy students' needs and desires. In fact, the study aimed to assess the effect of organizational capacity, motivation, or intervention capacity on online teaching readiness and satisfaction of students' learning during COVID-19 broke out or future unforeseen circumstances. 90 teachers and 135 students participated in an online survey and responded the online teaching readiness questionnaire and e-learning satisfaction scale. Structural equation modeling (SEM) was performed to evaluate the online teaching readiness and online learning satisfaction models. A partial correlation matrix, CMIN, CFI, PCFI; NCP, FMIN, RMSEA, AIC, and ECVI was generated by the AMOS 21.0 program to calculate path coefficients and the overall model fit. The authors claimed that organizational capacity, motivation, and intervention capacity significantly relate to teachers' online teaching readiness. Synchronous e learning (e.g., Skype/Zoom/WebEx) results of the direct effects of students' learning performance, need satisfaction, openness to learning, self-concept, self-pace, problem solving, self-assessing, love of learning, creativity, and motivation
\end{abstract}

Keywords

Era of COVID-19, intervention capacity, motivation, online teaching readiness, organizational capacity, satisfy students' learning

Article Received: 10 August 2020, Revised: 25 October 2020, Accepted: 18 November 2020

\section{Introduction}

COVID-19 can spread with contact; precaution may stop the spread of the infection (Bai et al., 2020; Lai et al., 2020; World Health Organization, 2020a). Consequently, many colleges and schools have been shut to limit the spread of the infection. India led a review on advanced education and saw that there are 993 colleges, 39931 institutions, and 10725 organizations that stopped formal education rather than motivated their students to join the online platform to access the online instructions. The organizational capacity, motivation, and intervention capacity has significant role in providing instruction and knowledge to the students staying outside the campus as well as many students are unable to return to the campus due to lack of communication and transportation facilities during COVID-19 (Basilaia \& Kvavadze, 2020). Government and the authority of private organizations are permitting instructive organizations to embrace web-based learning and imbue a virtual learning environment (Jena et al.,2020). At present, videoconferencing applications like Zoom and Webex are using in higher education. Be that as it may, teachers are attempting to keep up a similar profundity of commitment with students and trying to improve in self-paced with selfdirected learning. Organizational capacity, motivation, and intervention capacity has directly affected online teaching readiness. In addition, organizational skills, technological skills, social skill, and learning management system are the components of organizational capacity those directly affect teachers online teaching readiness and students learning performance (Jena et al., 2015; Kandri, 2020). Recently, the pandemic forced the teachers and management to run the course in online and distance modes. Students are not satisfied in many aspects, like skill training and practical work, and cannot do hands-on activities that are not possible to workout outside the laboratory. The survey found that 1.5 billion students - near $90 \%$ of students in the world - are not, at this point; ready to attend regular classrooms because of highly vulnerable coronavirus and its infection. However, the recent question is whether organizational capacity, motivation, or intervention capacity affects online teaching readiness and satisfies students' learning aspects in the Era of COVID-19 broke out or in any future unforeseen circumstances (Salovey, 2020a, b).

\section{Organizational capability model}

Organizational capability is organizational execution (Andrade, 2019) and the capability to perform organizational skills, technological skills, social skill, and teaching management (Xiaoying and Yong, 2017). It's an organized social framework of gatherings and cooperating people to meet some concurred on goals (Greenberg and Baron, 2008; Yu-Lee, 2002). The organizational capacity model is an individual capability proposed by Nguyen and Zeng classified into three components i.e., organizational information, skills, and feeling. These elements focused on interaction, conflict management, appreciation for diversity, and successful teamwork (Jena and Gupta, 2019). Moreover, the organization highlighted work, goals, and people as the contextual factors influencing the organizational elements (Piña, 2017). Reitz (1987) found that a work-driven association model is a social unit that has been intentionally intended to accomplish some particular objective. Hatch and Cunliffe, 2013 found that association is a very much planned and overseen arrangement of choice and activity 
coordinated towards expressed goals. In addition, Smith and Coleman (2018) found that organizational readiness is the sum resource and management where staff accountability and readiness is crucial to disseminate knowledge through online and offline modes.

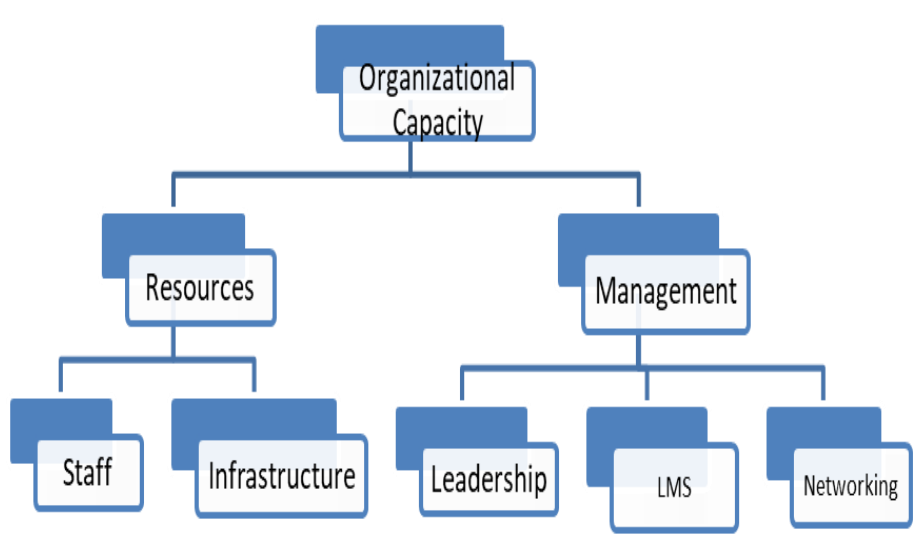

Fig 1 Organizational capability model

Rigau et al. (2019) found the organizational capacity promotes leadership, learning management system, networking, those engage learners in research and intervention, and the level of organizational learning for academic staff readiness (Ishak and Mansor, 2020). Organizational capacity concepts are directly linked with communication, conflict resolution, appreciation for diversity, and teamwork (Andrade, 2019).

\section{Motivation models}

Mindset theory

Prof. Carol Dweck, an American analyst, discovered that we, as a whole, have various convictions about the hidden idea of capacity. People with a developed mindset accept that insight and abilities can be created through exertion, perseverance, attempting multiple techniques, and gaining from botches since power something intrinsic (Molden and Dweck, 2006). Dweck's hypothesis of motivation intervenes in the connection between educator mindset and instructing practices. This mental hypothesis of motivation might help educate and learn (Richardson et al., 2020). Students who clarify their disappointment because of an absence of capacity may well respond distinctively to a blow than students who accuse their exertion, which is ordinarily more heavily influenced by them (Weiner and Kukla, 1970).

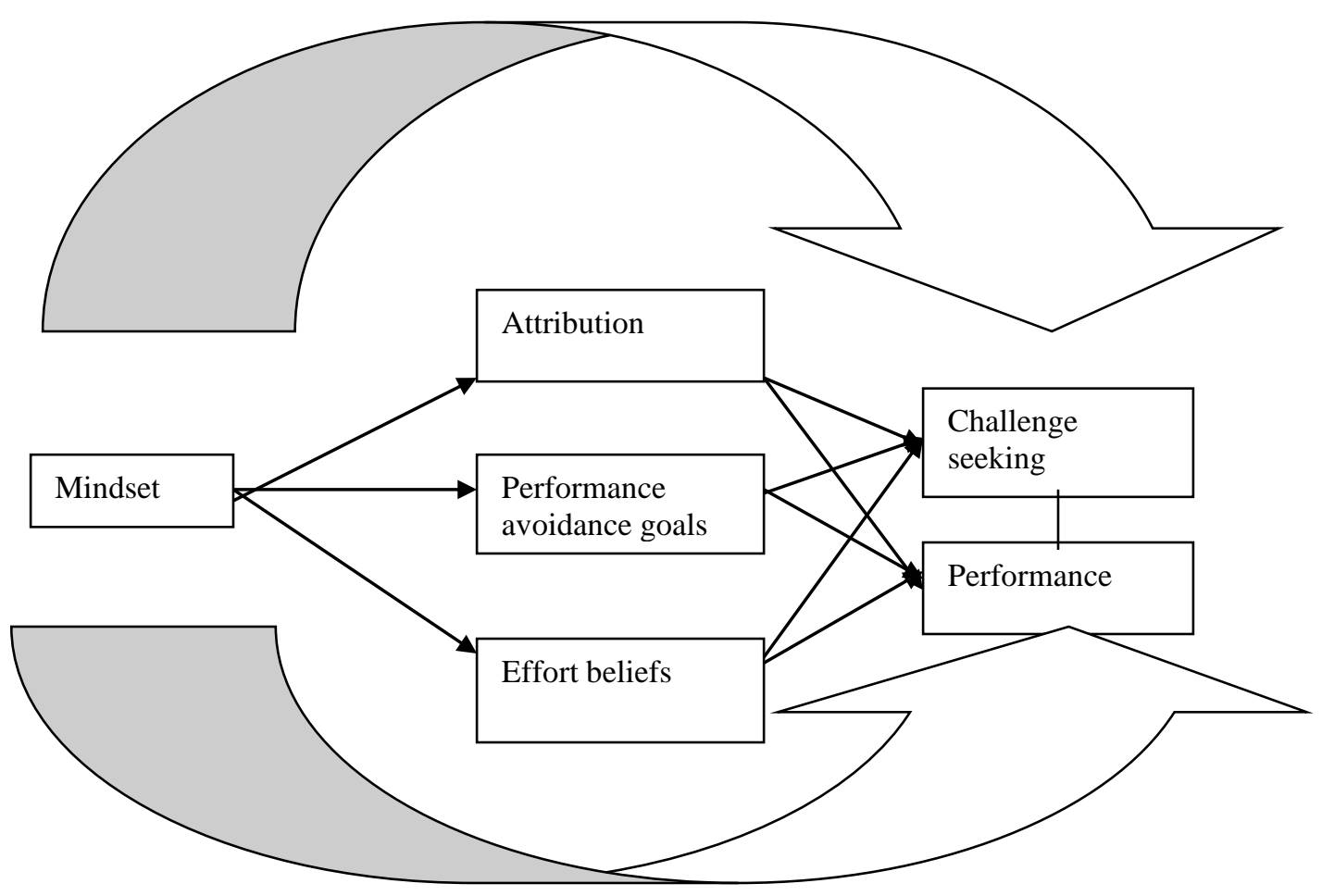

Fig- mindset

Presently, a few convictions are not confined thoughts yet instead can serve a sorting out capacity, uniting objectives, beliefs, and practices into what may be known as a "meaning framework" (Hong et al., 1999; Molden and 
Dweck, 2006). Exploration has indicated that mindsets can be changed generally rapidly, and there are many things that guardians and families can do to help. The following are a couple of tips and thoughts that can help advance a development mindset in youth. It is generally accepted that bringing down our desires goes humans' confidence, yet this isn't the situation. Having exclusive standards works like an unavoidable outcome. Nguyen (2020) discovered dependable thoughts could help educators encourage a reliable mindset; however, making a mindset is troublesome (Wright, 2018). Educators' attitude needs to develop along with four measurements, such as attribution, goal, challenge, and belief (Goodwin, 2020). Teachers' mindsets influenced learning practice among the understudies (Jena and Bhabatosh, 2016). Exploration confirmations found that there is expanded acknowledgment of the impact of instructors' convictions on understudies' capacities (Seaton, 2018). It demonstrated that you accept they can do it, which positively affects their own beliefs, conduct, and results.

\section{Self-determination theory}

Self-determination theory is a framework of human motivation expresses a meta-theory for sketching out influential research and legitimate speculation that characterizes intrinsic and extrinsic sources of motivation and social turn of events (Ryan and Deci, 2000). Selfdetermination theory focuses on how social and social segments empower people's inclination of volition and action, despite their thriving and the idea of interaction (Turner,2019; Weiner and Kukla,1970). The satisfaction of fundamental needs developed self-controlled motivation connected with the extended course in web, based teaching ((Hong et al.,1999; Hsu et al., 2019). Furthermore, this helps self-organization of learning and self-coordinated learning and empowers learning affiliation. In addition, internet learning has an impact on mental realizing affects flexible learning continuation and high expectations (Jacobi, 2019; Yang et al., 2019). The fulfillment of essential mental needs improved self-controlled inspiration related to expanded coucourses online learning (Hsu et al., 2019). And these support, self-administration of learning, and self-directed learning and encourage learning association. Online learning directly impacts students' psychology, but teachers' readiness is crucial in promoting learning (Jena and Thengal, 2017a,b). Students' learning experience is a fundamental part of understanding the significant segments in simulation innovation and human association and applications that improve students' motivation (Huang et al., 2019). Online learning executed self-idea, self-pace, critical thinking, love of learning, inventiveness, and inspiration (Yang et al. 2019).

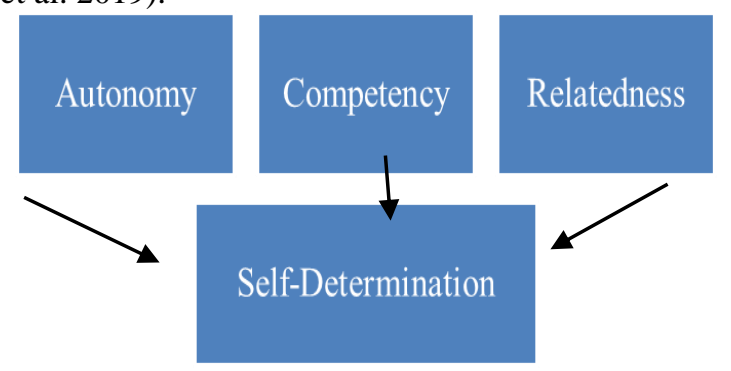

Fig 3 Self-determination model

\section{Intervention capacity of teachers}

The extreme impact of COVID-19 has shaken the world (Abdulamir and Hafidh, 2020). Further, numerous administration establishments have unexpectedly closed down their associations and attempted to stop the spread of the COVID-19 pandemic (Ait Addi et al., 2020). Students of KG to PG are affected. The UNESCO report assessed that the COVID pandemic will unfairly influence in excess of 290 million students across 22 countries. E-learning and Distant learning is only substitute of face to face learning (Coppola et al., 2002) that students realized (Naciri et al., 2020). This will empower comprehensive instruction by encouraging learning across differing geologies in India (Jena, 2018). Furthermore, it will allow to teachers to consider adjusted learning answers for each students (Paulsen, 1995). Workforce admittance to proficient turn of events and coaching, confinement and connectedness to the grounds network, and scholarly opportunity and educational program control have huge ramifications for internet instructing and understudy learning. In the wake of COVID19, educational institutions are confronted with online learning, and these incidents have no teachers and organizations seen never before (Perrotta and Bohan, 2020). Administrators observed that teachers with and without online teaching experience rotated to web based educating, and essentially all executives showed that the individuals who didn't have web based training experience were currently figuring out how to educate on the web (Huang and Hsiao, 2012; Jena,2019). Whether or not staff had past experience showing on the web or not, numerous personnel detailed that they were utilizing new showing strategies (Johnson et al 2020). Online teaching and its troublesome effect on advanced education affected the students of both public and private organizations because of the teachers without the knowledge of online teaching experience (Windes and Lesht, 2014) and there is a huge distinction between teachers of various institutions faced difficulties (Aldosemani, 2020).

\section{Online teaching readiness}

Staff often report that teaching on the web is fulfilling in light of the fact that it presents a intellectual challenge (Akopyan, 2009). The web based learning climate furnishes teachers with the occasion to try different things with new advances and investigate new educational methodologies (Anderson et al., 2001). Major (2010) found that instructing on the web introduced new difficulties that changed the manner in which staff drew closer and contemplated educating. Working through these difficulties was compensating in light of the fact that it improved online teaching over face-to-face teaching practices (Berge, 1995). Online teaching needs readiness and self-motivation, organizational capacity, intervention capacity (Betts, 2014) and teachers' patients and skills of delivering the lecture (Biswas and Das, 2011).). Many teachers didn't agree online teaching in light of the fact that they accept that online teaching is health affecting and they would prefer not to take classes (Bolliger and Wasilik, 2009). As per public overview, teachers' readiness and organizational support could help in online teaching (Allen and Seaman, 2013). 
Moreover, online teaching, is a new stress that teachers do not have the specialized abilities important to show on the web and are threatened by the web based learning climate (Garrison et al., 2000). Teachers are additionally worried about their changing function in the online climate (Giannoni and Tesone, 2003). A few teachers have archived the intellectual, administrative, and emotional advances in online teaching experience as they performed better and students liked their performance (Panda and Mishra, 2007).

\section{Objective}

Based on the literature and the importance of the recent research question, the present study aimed to assess the effect of organizational capacity, motivation, or intervention capacity on online teaching readiness and satisfaction of students' learning during COVID-19 broke out or future unforeseen circumstances.

\section{Method}

\section{Participants}

During this pandemic COVID-19 era, the students of Northeastern states of India are accessing teaching in online modes, and recently teachers are providing the instruction through E-mail, WhatsApp, YouTube, Facebook Skype, WebEx Zoom, Video conferencing. WHO advised the educational institutions to provide online instruction and worldwide educational institutions are offering instruction through E-mail, WhatsApp, YouTube, Facebook, and Skype mode. Convenience sampling technique used because large numbers of e mail IDs of the respondents were collected and the author expected their participation in this study without knowing their demographic characteristics. The teachers and students were the participants. The respondents have freedom to accept or decline to respond the survey as a result. The author has observed that uninhibited psychological states among the participants invade individual privacy caused large numbers of refusal to participate in this academic online survey (Conceição, 2006) made this email survey limited in their ability to provide the generalizability of results due to self-selection, non-random and non-probabilistic sampling. Finally, 90 teachers and 135 students of 50 colleges and 15 teacher-training institutions in the Northeast region of India responded this online survey and helped to assess the effect of organizational capacity, motivation, or intervention capacity on online teaching readiness and satisfaction of students' learning during COVID-19 broke out or future unforeseen circumstances (Toquero, 2020).

\section{Procedure of online survey}

Email survey approach used in this research included demographic data and rating scale with proper directions (Cho and LaRose, 1999). The study begins with a requesting page followed by the email greeting to set up a believing relationship with the forthcoming respondent that empowers to continue into the survey (Stanton, 1998). To do this, the author 1) set up the guidelines of the survey, 2) explained the survey reason, 3) highlighted the prominence issues of the survey, 4) open permission to researchers through email, 6) explained the scoring procedure, and, 7) illustrated the validity and credibility of the survey. Before demographic information section, a page for "select in" asked about to view the items of the survey (Andrews et al., 2001). By submitting an email address, the respondents started response to the items.

\section{Instrumentation}

\section{Online teaching readiness scale}

Table-1 Sample e-mail survey

Wang and Wang (2009) who used the online teaching readiness model having 34 -items built up a web based learning segment. The model was later tried with teachers who used online teaching with additional five items (i.e.39 items). The online teaching readiness scale has 31 items distributed in three sections evaluate the responses over the six factors. The five-point Likert-type scale, ranged from "1 $=$ strongly disagree "to " $5=$ agree included 7 zones such as 1) economics, 2) web learning experience, 3) web teaching experience,4) learning management systems and technologies,5) capable development,6) web teaching strategies, and 7) criticalness of online teaching strategies. Items are set up in an online grounds with the assistance of two educators with aptitude in web based instructing and learning assessed the online study and tended to any worries with finishing it on the web, alongside remarks or proposals concerning the study (Dillman, 2000). Truth be told, the instrument was overhauled dependent on their proposals. It was then pre-attempted preceding control in the educators' who utilized online courses in this semester. All these items are prepared by consulting with the expert and only developed for teachers who use online teaching approaches (Preece et al., 2002).

\section{E-learning satisfaction questionnaire}

The E-learning satisfaction questionnaire included three significant segments: (a) demographic data, (b) internet experience, and (c) mentalities toward e-learning. The demographic part covered gender and the field of study; online learning segment requested to demonstrate whether they had insight of utilizing internet browsers, email, word handling bundles, and coding. These 4 inquiries are each of the 5-point Likert scales (from 1, which implies "no experience" to 5, which implies "well experienced"). In perspectives toward e-learning, respondents were approached to show their mentalities toward e-learning. These 15 inquiries all received 5-point Likert scales (from 1, which implies "emphatically dissent" to 5, which implies "firmly agree"). The alpha dependability of teacher perspectives toward e-learning was to be exceptionally acknowledged $(\alpha=0.95)$. The high alpha dependability gives uphold for survey content unwavering quality (Freeze et al, 2010). The Pearson connection coefficients among the factors are introduced. The bivariate connections showed that a large number of the factors altogether associated with one another however are on the whole under 0.80 . Concerning the logical system for evaluating the prescient model, various relapse investigation is a suitable 
multivariate expository technique (Witmer et al., 1999). Basically, multicollinearity can be controlled in two different ways: (1) connection between's autonomous factors should all be under 0.8 (Emory and Cooper, 1991). In this investigation, multicollinearity was precluded because the relationship between's autonomous factors were all under 0.8 and the VIFs were all under 10. It was then preattempted before regulate in the students' who utilized online courses in this semester. Nonetheless, the study stayed open for two semesters after which the reactions were examined utilizing the Statistical Package for the Social Science (SPSS) version 21.0.

\section{Data analysis}

Prior to analyzing the datasets, the author screened and changed the missing qualities

Technology
I use Microsoft Word and
PowerPoint during the preparation
of e-contents.
Usually
Sometimes
I use file monitoring system.
Usually
I use multimedia, animation and
cartoons in my presentation.
Usually
Sometimes
I provide online assignments,
and in zoom.
Usiom in Google meet, WebEx
Usually
Sometimes
Rarely

exceptions, and ordinariness. The greatest desire count was used in this examination to credit missing characteristics, for it gives fair appraisals when the unpredicted and the peculiarities of data analyzed factors (Neter and Kutner, 1990). The model sample size was greater than 150 , this assessment applied the models more unmistakable regarded an inconsistency. A data analysis exhibited that the results didn't change by and large ensuing to deleting inconsistencies; as needs be, the exemptions were impedance. A fragmented correlation matrix was confusing showed fragmentary relationship to figure way the coefficients and the overall model fit (Kaplan, 2000). To acquaint the degree with which the conjectured of online learning status model fit tested data, the $\chi 2$ estimations were used close by four fit records proposed by $\mathrm{Hu}$ and Bentler (1998) recorded chi-square, CMIN, CFI, PCFI, NCP, FMIN, RMSEA, AIC, and ECVI (Kline, 2005).

\section{Results}

The author assumed that organizational capacity, motivation, and intervention capacity positively affects online teaching readiness.

\section{Modell online teaching readiness}

Fig. 1 illustrates standardized path coefficients and fit indices of organizational capacity, motivation, intervention capacity online teaching readiness model. The fit indices suggested a good fit of data, $\chi 2=(53, \mathrm{~N}=90)=454.679$, $\mathrm{p}<.005 ; \quad \mathrm{CMIN}=8.579, \quad \mathrm{CFI}=.798, \quad$ PCFI $=.542$; $\mathrm{NCP}=401.679, \quad \mathrm{FMIN}=4.289, \quad \mathrm{RMSEA}=.267$, $\mathrm{AIC}=528.679$, and $\mathrm{ECVI}=4.988$. Regarding the structural paths, organizational capacity positively predicted organizational skills $(\beta=.53 \mathrm{p}<.001)$, technological skills $(\beta$ $=.33 \mathrm{p}<.001)$, social skills $(\beta=.33 \mathrm{p}<.001)$, and learning management system $(\beta=.36 \quad \mathrm{p}<.001)$. Regarding the structural paths, mindset $(\beta=.22 \quad p<.001)$, and selfdetermination $(\beta=.27 \quad p<.001)$ is positively predicted motivation. In standardized path coefficients, the intervention capacity determination yields a significant positive relation with online teaching experience $(\beta=.56$ $\mathrm{p}<.001)$ and pedagogical skills $(\beta .50 \mathrm{p}<.001)$. In addition, organizational capacity significantly predicted motivation $(\beta=1.00)$ and intervention capacity $(\beta=1.00)$. In this structural path, motivation $(\beta=.43 \mathrm{p}<.001)$ and intervention capacity $(\beta=.97 p<.001)$ are the positive and significant predictor of online teaching readiness. Nevertheless, organizational capacity $(\beta=-.41 \mathrm{p}<.001)$ negatively predicted online teaching readiness.

However, online instruction and self-regulation did not yield a significant direct effect on the outcome variable.

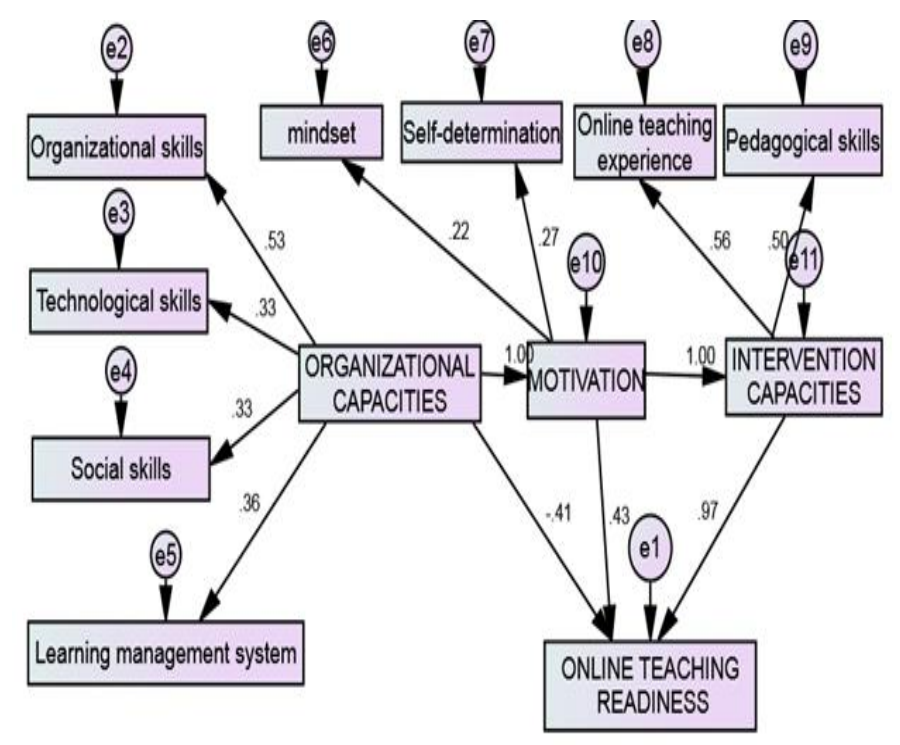

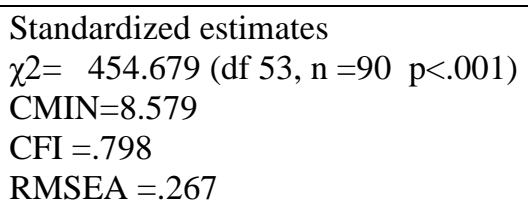

Model 2 students' need satisfaction of online learning

The author assumed that synchronous and asynchronous learning positively affects students' need satisfaction of learning. Fig. 2 illustrates standardized path coefficients and fit indices of asynchronous e-learning (e.g. Email/YouTube/WhatsApp) and synchronous e-learning (e.g., Skype/Zoom/WebEx) students' need satisfaction of learning 
model. The fit indices suggested a good fit of data, $\chi 2=$ $(\mathrm{df}=81, \mathrm{~N}=135,4340.584, \mathrm{p}<.001 ; \mathrm{CMIN}=53.587$, CFI $=.082, \quad$ PCFI $=.055 ; \quad \mathrm{NCP}=4259.584, \quad \mathrm{FMIN}=16.442$, RMSEA $=.446, \quad \mathrm{AIC}=4448.584$, and $\mathrm{ECVI}=16.851$. Regarding the structural paths, E-mail/YouTube/WhatsApp predicted students' performance $(\beta=-.75 \quad \mathrm{p}<.005)$, need satisfaction $(\beta=-.72 p<.005)$, openness to learning $(\beta=-.75$ $\mathrm{p}<.005), \quad$ self-concept $(\beta=-.76 \mathrm{p}<.005), \quad \operatorname{self}-\operatorname{pace}(\beta=-.75$ $\mathrm{p}<.005)$, problem solving $(\beta=-.75 \mathrm{p}<.005)$, self-assessing $(\beta=$ -.75 $p<.005), \quad$ love of learning $(\beta=.75 \quad p<.005)$, creativity $(\beta=.75 p<.005)$, and motivation $(\beta=.76 p<.005)$. In standardized path coefficients, the Skype/Zoom/WebEx determination yields a significant relation with students' performance $(\beta=-.72 \quad p<.005)$, need $\operatorname{satisfaction}(\beta=-.75$ $\mathrm{p}<.005)$, openness to learning $(\beta=.71 \mathrm{p}<.005)$, self-concept $(\beta=.76 \mathrm{p}<.005)$, self-pace $(\beta=.76 \mathrm{p}<.005)$, problem solving $(\beta=.75 p<.005)$, self-assessing $(\beta=.74 p<.005)$, love of learning $(\beta=.75 p<.005)$, creativity $(\beta=.75 p<.005)$, and motivation $(\beta=.76 \mathrm{p}<.005)$.

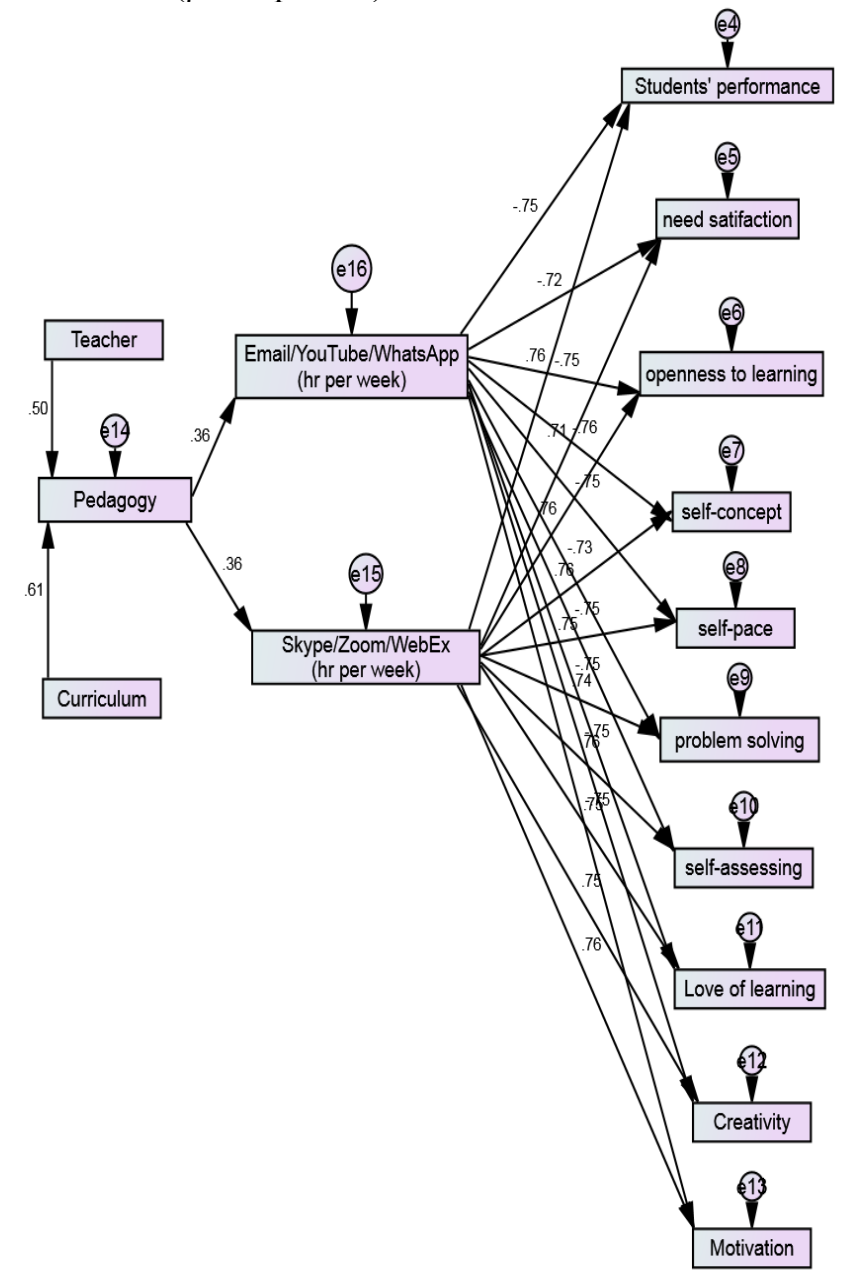

Standardized estimates

$\chi 2=4340.584(\mathrm{df}=81, \mathrm{n}=135, \mathrm{p}<.001)$

$\mathrm{CMIN}=53.587$

$\mathrm{CFI}=.082$

RMSEA $=.446$

However, asynchronous e-learning (e.g. Email/YouTube/WhatsApp) and synchronous e-learning (e.g.,
Skype/Zoom/WebEx) yield a significant direct effect on the outcome variables of students' need satisfaction of online learning. First, the path Modell online teaching readiness fit indices of organizational capacity, motivation; intervention capacity was significant supported online teaching readiness. Second, for the category of Email/YouTube/WhatsApp, need satisfaction was the strongest and positive predictor of students' performance, need satisfaction, openness to learning, self-concept, selfpace, problem solving, self-assessing, love of learning, creativity, and motivation. Third, as shown in fig 2, Skype/Zoom/WebEx has the direct effect on students' performance, need satisfaction, openness to learning, selfconcept, self-pace, problem solving, self-assessing, love of learning, creativity, and motivation.

\section{Discussion}

The aim for this study was to test the impacts of organizational capacity, motivation, and intervention capacity positively on online teaching readiness. An online teaching readiness model depicting interrelationships among organizational capacity, motivation, and intervention capacity empirically tested for online teaching readiness, and the result was consistent with (Aldosemani,2020; lker et al.,2010; Liyan and Janette, 2007). Kuan-Chung and SyhJong (2010) found an effect of organizational capacity, motivation, and intervention capacity on online teaching readiness. In addition, organizational skills, technological skills, social skill, and learning management system have significant relations with organizational capacity those directly effects the motivation and online teaching readiness. In addition, mindset and self-determination of teachers has directly affect motivation, intervention capacities and online teaching readiness. Online teaching readiness needs of organizational capacities, motivation and instructional capacities. Teachers' readiness depends on online teaching experience and pedagogical skills of the teachers. For instance, teachers can collaborative synchronous e learning (Yengin et al., 2011; Windes et al., (2019), collaborative asynchronous (Kuan-Chung Chen and Syh-Jong Jang, 2010; Panda, \& Mishra, 2007 and online pedagogical skills to promote self-regulation and self directed learning strategies (Smith, and Coleman, 2018). The author suggests organizational capacities; the motivation and intervention capacities have online teaching readiness (Xiaoying and Yong 2017). Teachers' online teaching readiness (Huang et al., 2019; Johnson, Veletsianos, Seaman, 2020; Kuan-Chung and Syh-Jong, 2010) that revealed mindset to be positively associated with motivation whereas "self-determination" had also positive effects. The organizational capacities to online teaching readiness with the findings that teachers' organizational capacity and (Hsu et al., 2019; Huang \& Hsiao, 2012). The author has hoped (e.g., $\alpha=.79$ for the online teaching readiness scale; $\mathrm{CV}=.65)$, Online teaching readiness was directly explained by organizational skills, technological skills, social skill, learning management system, and mindset and self-determination categories. Teaching readiness context, motivation and intervention capacities teachers' online teaching consequences.

This study has assumed that synchronous and asynchronous learning positively affects students' need satisfaction of 
learning. It shown the teacher and curriculum has direct relations with pedagogy through students' need satisfaction model tests (Jena et al., 2020). The asynchronous e-learning (e.g. E-mail/YouTube/WhatsApp) and synchronous elearning (e.g., Skype/Zoom/WebEx) results of the indirect effects of students' learning performance, need satisfaction, openness to learning, self-concept, self-pace, problem solving, self-assessing, love of learning, creativity, and motivation (Betts, 2014). Furthermore, synchronous elearning (e.g., Skype/Zoom/WebEx) students' learning performance, need satisfaction, openness to learning, selfconcept, self-pace, problem solving, self-assessing, love of learning, creativity, and motivation (Coppola, Hiltz, \& Rotter, 2002). students' learning performance, need satisfaction, openness to learning, self-concept, self-pace, problem solving, self-assessing, love of learning, creativity, and motivation. asynchronous e-learning (e.g. Email/YouTube/WhatsApp) of students' learning performance, need satisfaction, openness to learning, selfconcept, self-pace, problem solving, self-assessing, love of learning, creativity, and motivation was with the findings that teachers' synchronous e-learning (e.g., Skype/Zoom/WebEx) results of the direct effects of students' learning performance, need satisfaction, openness to learning, self-concept, self-pace, problem solving, selfassessing, love of learning, creativity, and motivation organizational capacity and self- (Kleickmann et al., 2013) valid as the author has hoped (e.g., $\alpha=.80$ for the e-learning satisfaction questionnaire; $\mathrm{CV}=.75)$, an E-learning satisfaction was directly explained by asynchronous elearning (e.g. E- mail/YouTube/ WhatsApp) and synchronous e-learning (e.g., Skype/Zoom/WebEx) categories (Giannoni \& Tesone,2003). Students' e-learning satisfaction context, learning performance, need satisfaction, openness to learning, self-concept, self-pace, problem solving, self-assessing, love of learning, creativity, and motivation have salient influence on teachers' online teaching consequences (Huang et al., 2019).

The teachers and students are sharing the e-contents through E-mail and WhatsApp, YouTube and Facebook, Skype and WebEx, Zoom and Video conferencing. All the institutions have qualified skilled teachers have good content and idea of delivering the lessons. Similarly, all the teachers were providing good e-contents to students. The study reveals that every institution has qualified teachers who are maintaining institutions have a flexible curriculum, timetable and they are using teaching-learning materials during curriculum transaction. They have good online platforms with a sufficient number of teachers knowing delivering the electure. Students are satisfied with e-learning and educational technology and they satisfied with present virtual institutional management. In addition, students are satisfied with pupil-pupil virtual interaction and getting space for self-learning in this teachers-students collaborative e-classroom. Because of COVID -19 issues, they are using modern technology in the teaching-learning process with individual and group e-learning space (Sintema, 2020). Contents uploaded for students are well-arranged and well accessible where teachers-students are satisfied with synchronous interaction (Author et al., 2019). Yet, there is a glaring weakness as tests must be delayed. Assessments can't be directed on the web. It isn't just the subject of granting persistent and continuous picking up during the flare-up of COVID 19 pandemic (Aljofan, \& Gaipov, 2020). Using innovation, we can, if not give a solid option in contrast to the regular instruction framework, alleviate and make up for the obstacles presented and bother caused due to COVID 19 pandemic to the training framework and students by expansion (Bacow, 2020). Learning, as is commonly said, is a consistent and ever-developing procedure. The instructive organizations in India, from schools to colleges, can utilize this current misfortune as a surprisingly positive turn of events and make computerized training a significant piece of the learning procedure for all students later on.

\section{Conclusion}

The author claimed that organizational capacity, motivation, intervention capacity has significant relation with teachers' online teaching readiness. As per institutional capabilities, teachers are motivating and providing online instruction to the students to satisfy the needs and desires of learning. In the scene of the pandemic, the work from home culture is affecting India. social isolating is prescribed as the best way to deal with the control of the spread of COVID 19, associations are gone up against a remarkable trial of promising it is old news whether or not every person is working indirectly (Wilder-Smith et al., 2020). Thusly, not simply agents or new establishments in India have chosen online modes like Zoom App to remain related with their laborers who are working from their homes yet moreover the enlightening associations have settled on different propelled stages to support learning for their understudies (Toquero, 2020). Teachers are following the new rule and giving their important guidance through E-mail, WhatsApp, YouTube, Facebook Skype, WebEx Zoom, Videoconferencing (Jena, 2019). The explanation, the reason is that COVID - 19 is exceptionally irresistible requirements instructive administration without open social occasions (Bai et al., 2020). Salovey, (2020a; Salovey, 2020b) saw that the COVID-19 may advance in stretching out online guidance to end of spring semester; grounds, and staffing contemplations manner. Akopyan, 2009 found that the thoughts of online instruction have a positive relationship with the students' learning performance, need satisfaction, openness to learning, self-concept, self-pace, problem solving, self-assessing, love of learning, creativity, and motivation (Usak et al., 2020). In any case, the question rises why e-learning is certainly not a practical answer for the COVID-19 instruction emergency in India (WilderSmith et al., 1999). Overall, trust, the ongoing pandemic made an open door for change in instructive methodologies and presentation of virtual training in all degrees of training. As author doesn't have the foggiest idea of how long the pandemic circumstance will proceed, a progressive move towards the on the web/virtual training is the interest of the current emergency. Virtual training is the most favored method of instruction during this season of emergency because of the flare-up of Covid-19. The post-COVID-19 training is by all accounts instruction with generally acknowledged on the web/virtual instruction, which may maybe, be an equal arrangement of training. Instructors and students ought to be prepared to use a web-based 
encouraging learning process utilizing innovation (Pravat, 2020c; Ulmer et al., 2007). Synchronous e-learning has direct effects on students' learning performance, need satisfaction, openness to learning, self-concept, self-pace, problem solving, self-assessing, love of learning, creativity, and motivation (Rossman, 1999).

The teachers and other supporting staff are working to promote learners through synchronous and asynchronous elearning.

Opportunity\# 1 A vision of the online learning statement during COVID-19 is fundamentally different from the online learning mission statement, which describes the enormous requirements and accessibility to realize the vision. However, online learning vision statements require thinking from the end to backward. In the article of Basilaia et al., 2020 it was justified that people of Georgia believed in the transition to online education in schools during COVID-19 would be a new approach. Not only was that these techniques could be the quality indicators in teacher education programs. But this vision statement in the world of education context maybe a mission statement because of the rapid inaccessibility of internet problems \& concern in the learning process (Goel et al., 2012). And in this context, the author agrees that online learning is the reflective dimension in higher and school education, and the ultimate way to reach the goal.

Opportunity\# 2 lesson to maintain accountability during a future pandemic

UNESCO 2016a stressed on professional accountability and quality control in online and distance mode of learning. Staff readiness and their responsibility to prepare e-learning content to be the practical answers to the students in the future pandemic. In a survey report of Jaime Savvedra, 2020, the Global Director, Education Global Practice 58\% of 262 university and college respondents are thinking about or have determined to stay completely on line for the fall 2020 semester and $62 \%$ are thinking about decreasing, or have decreased, the wide variety of in-person guides for autumn 2020. So, the author is highly emphasized on the staff's accountability and responsibility and their readiness to provide service to the students' in future pandemic situations. Staff readiness and their efficiency, work culture, developing online learning resources, or e-contents may help give the students through E-mail and WhatsApp, YouTube and Facebook, Skype and WebEx, Zoom, and Video conferencing in the future pandemic.

Opportunity \# 3 Synchronous and Asynchronous e learning and App learning

In the article of Granda et al., 2010; Stewart et al., 2011: Olaniran, 2006 it was found that 240 college students of Spain preferred synchronous e-learning even during the college hours because students realized web conferencing is an alternate learning of face to face instruction. E-Mail has additionally huge impacts on learning execution, thinking abilities, and leader capacities of students. The author agrees with these ideas because, in the last two decades, the application of ICTs has proved to improve students' performance in the teaching-learning process. E-contents have a significant effect on the learning environment where they can learn contents quickly, respond to any queries, enjoy e-classroom situations, and react to any stimuli, whether it may be alone or with friends in a small or large group. It is recommended that HE institutions need to have essential ICT Infrastructure to suitably turn out online learning.

\section{Limitation and suggestions}

Besides efforts, this study has a few limitations. First, this study was conducted in pandemic situation where all teachers were bound to provide online instruction because of institutional management and decision which may somewhat restrict its degree of generalizability (Rockwell et al., 1999). This study designed a correlational research predicted online teaching readiness and e learning satisfaction in recent COVID-19 era. Although online teaching readiness and e-learning satisfaction model contained directional paths and validated through SEM but the evidence was still insufficient to draw conclusion. In this case, organizational capacity positively predicted organizational skills, technological skills, social skills, and learning management system indirectly related with online teaching readiness. Hopefully, it is due to the high and homogeneous mean value of the dependent variables available in sample and online teaching readiness

Data availability

Data transparency is available upon request.

Ethics declarations

Conflict of interest

The authors declare that they have no conflict of interest.

\section{References}

[1] Abdulamir, A. S., \& Hafidh, R. R. (2020). The possible immunological pathways for the variable immunopathogenesis of COVID_-19 infections among healthy adults, elderly and children. Electronic Journal of General Medicine, 17(4), em202.

https://doi.org/10.29333/ejgm/7850

[2] Ait Addi, R., Benksim, A., Amine, M., \& Cherkaoui, M. (2020). Asymptomatic COVID-19 Infection Management: The Key to Stop COVID-19. Journal of Clinical and Experimental Investigations, 11(3), https://doi.org/10.5799/jcei/7866

em00737.

[3] Akopyan, L.S. (2009). Novyi podhod k klassificatcii strachov [New approach to the classification of fears]. News of Samara Scientific Center of the Russian Academy of Sciences, 4, 1472-1475.

[4] Aldosemani, T.I. (2020). Onwards Ethically Responsive Online Education: Variables and Strategies from Educators' 
Perspective. Journal of Education and Learning, 9 (1), 79-86.

[5] Aljofan, M., \& Gaipov, A. (2020). Chloroquine and COVID-19: A light at the end of the tunnel, or is it another train? Electronic Journal of General Medicine, 17(4), em207. https://doi.org/10.29333/ejgm/7863

[6] Allen, I. E., \& Seaman, J. (2013). Changing course: Ten years of tracking online education in the United States. Babson Park, MA: Babson Survey Research Group and Quahog Research Group.

http://www.onlinelearningsurvey.com/repo rts/changingcourse.pdf

[7] Anderson, T., Rourke, L., Garrison, R., \& Archer, W. (2001). Assessing teaching presence in a computer conferencing context. JALN, 5(2), 1-17.

[8] Andrade, M. S. (2019). ePortfolios and Online Learning: Applying Concepts of Organizational Behavior. International Journal of E-Learning \& Distance Education, 34(1).

[9] Andrews, D., Preece, J., \& Turoff, M. (January 2001). A Conceptual Framework for Demographic Groups. Resistant to Online Community Interaction. Presented at the HICSS 2001 Conference. Honolulu, HI.

[10] Bacow, L. (2020, March 10). COVID-19Moving classes online, other updates. [Community Message]. Harvard University.

https://www.harvard.edu/covid-19moving-classes-online-other-updates

[11] Bai,Y.,Yao,L.,Wei,T.,Tian,F.,Jin,D.Y.,Che n,L.,\&Wang,M.(2020).Presumed asymptomatic carrier transmission of COVID-19. Journal of the American Medical Association, 323 (14), 14061407.https://doi.org/10.1001/jama.2020.25 65

[12] Basilaia, G., \& Kvavadze, D. (2020). Transition to Online Education in Schools during a SARS-CoV-2 Coronavirus (COVID-19) Pandemic in Georgia.
Pedagogical Research, 5(4), em0060. https://doi.org/10.29333/pr/7937

[13] Berge, S. L. (1995). Facilitating computer conferencing: Recommendations from the field. Educational Technology, 15 (1), 22$30 . \quad$ Retrieved from http://www.emoderators. Com/moderators/ teach_online. Html

[14] Betts, K. (2014). Factors influencing faculty participation \& retention in online $\&$ blended education. Online Journal of Distance Learning Administration, 17(1).Retrieved from http://www.westga.edu/ distance/ojdla/spr ing 171/betts171.html

[15] Biswas and Das (2011). Infrastructural status of teacher education. Journal of teacher and education, 4(2), 1-15.

[16] Bolliger, D. U., \& Wasilik, O. (2009). Factors influencing faculty satisfaction with online teaching and learning in higher education. Distance Education, 30(1), 103-116.

[17] Cho, H. \& LaRose, R. (1999). Privacy issues in Internet surveys. Social Science Computer Review, 17(4), 421-434.

[18] Conceição, S. C. O. (2006). Faculty lived experiences in the online environment. Adult Education Quarterly, 57(1), 26-45. doi:10.1177/1059601106292247

[19] Coppola, N. W., Hiltz, S. R., \& Rotter, N. G. (2002). Becoming a virtual professor: Pedagogical roles and asynchronous learning networks. Journal of Management Information Systems, 18(4), 169-189.

[20] Dillman, D.A. (2000.) Mail and web-based survey: the tailored design method. New York: John Wiley \& Sons.

[21] Emory, C. W., \& Cooper, D. R. (1991). Business research method (4th ed.). Homewood, IL: Irwin

[22] Freeze, R. D., Alshare, K. A., Lane, P. L., \& Wen, H. J. (2010). IS success model in e-learning context based on students' perceptions. Journal of Information Systems Education, 21(2), 173-184. 
[23] Garrison, D. R., Anderson, T., \& Archer, W. (2000). Critical inquiry in a text-based environment: Computer conferencing in higher education. The Internet and Higher Education, 2, 87-105.

[24] Giannoni, D. L., \& Tesone, D. V. (2003). What academic administrators should know to attract senior level faculty members to online learning environments. Online Journal of Distance Learning Administration, 6(1).

[25] Goodwin, A. L. (2020).Globalization, Global Mindsets and Teacher Education. Action in Teacher Education, 42(1), 6-18.

[26] Greenberg, J. and Baron, R.A. (2008). Behavior in Organizations. Pearson, Hoboken, 269-274.

[27] Hatch, M.J. and Cunliffe, A.L. (2013). Organization Theory: Modern, Symbolic, and Postmodern Perspectives. 3rd Edition, Oxford University Press, New York.

[28] Hong, Y. Y., Chiu, C. Y., Dweck, C. S., Lin, D. M. S., \& Wan, W. (1999). Implicit theories, attributions, and coping: A meaning system approach. Journal of Personality and Social Psychology, 77, 588-599.

[29] Hsu, Hui-Ching Kayla; Wang, Cong Vivi; Levesque-Bristol, Chantal (2019). Reexamining the Impact of SelfDetermination Theory on Learning Outcomes in the Online Learning Environment. Education and Information Technologies, 24 (3), 2159-2174.

[30] Huang, X. "Silvie,” \& Hsiao, E.-L. (2012). Synchronous and asynchronous communication in an online environment: Faculty experiences and perceptions. Quarterly Review of Distance Education, 13(1), 15-30, 49-50.

[31] Huang, Yu-Chih; Backman, S. J.; Backman, K. F.; McGuire, F. A.; Moore, DeWayne (2019). An Investigation of Motivation and Experience in Virtual Learning Environments: A SelfDetermination Theory. Education and Information Technologies, 24(1), 591-611.
[32] Iker, Y., Dilek, K., Adem, K., Ahmet, Y. (2010). Roles of teachers in e-learning: How to engage students \& how to get free e-learning and the future. Procedia Social and Behavioral Sciences, 2, 5775-5787

[33] Ishak, R.; Mansor, M. (2020). The Relationship between Knowledge Management and Organizational Learning with Academic Staff Readiness for Education 4.0. Eurasian Journal of Educational Research, 85, 169-184.

[34] Jacobi， L. (2018). What Motivates Students in the Online Communication Classroom? An Exploration of SelfDetermination Theory. Journal of Educators Online, 15 (2).

[35] Jena, A. K. (2018).Factors relating to Memory, Social Skill, Language Acquisition, Logical Reasoning, and Problem Solving Skills of Pre-school Children. International Journal of Research in Teacher Education, 9 (2), 36-50.

[36] Jena, A. K. (2019).Concept Map in Photosynthesis and its Effects on Achievement and Self-Classroom Management. International Journal of Research in Teacher Education, 10 (4), 118.

[37] Jena, A. K., Bhabatosh, P. (2016). Cognitive Developmental Phenomena of Pre-School Children In Relation To SocioEconomic Status, Anthropometric Status, and Home Environmental Status. iManager's Journal on Educational Psychology, 9 (2), 25-38.

[38] Jena, A. K., Bhattacharjee, S., Devi, J., Barman, M. (2020). Effects of Web 2.0 technology assisted Slideshare, YouTub and WhatsApp on Individual and Collaborative Learning Performance and Retention in Tissues System. The Online Journal of Distance Education and eLearning, 8 (1), 25-36.

[39] Jena, A. K., Bhattacharjee, S., Langthasa, P. (2015). Effects of Multimedia on Knowledge, Understanding, Skills, Practice and Confidence in Environmental Sustainability: A Non-Equivalent Pre- 
Test-Post-Test, Quasi Experimental Design. Journal of Educational Technology, 12 (3), 37-47.

[40] Jena, A. K., Gupta, S. (2019). Effects of Online Technology Based Scaffolding on Asynchronous Learning Performance of Students. Think India, 22 (14), 6919-6939.

[41] Jena, A. K., Thengal, N. (2017a). Levels of Self-actualization, Socio-economic Status and Job-satisfaction of University and College Teachers. International Journal of Research, 4 (14), 3811-3831.

[42] Jena, A. K., Thengal, N.(2017b).Selfactualization of University Teachers in relation to their Socioeconomic Status and Job-satisfaction. International Journal of Research, 4 (17), 1353-1364.

[43] Johnson, N.; Veletsianos, G.; Seaman, J. (2020). U.S. Faculty and Administrators' Experiences and Approaches in the Early Weeks of the COVID-19 Pandemic. Online Learning, 24(2), 6-21

[44] Kandri, S. (2020). How COVID-19 is driving a long-overdue revolution in education.

https://www.weforum.org/agenda/2020/05

/how-covid-19-is-sparking-a-revolutionin-higher-education/

[45] Kaplan, D. (2000). Structural equation modeling: Foundations and extensions. Thousand Oaks, CA: Sage.

[46] Kline, R. B. (2005). Principles and practice of structural equation modeling (2nd ed.).New York: Guilford Press.

[47] Kuan-Chung Chen, Syh-Jong Jang (2010). Motivation in online learning: Testing a model of self-determination theory. Computers in Human Behavior, 26, 741752

[48] Lai, C.-C., Shih, T.-P., Ko, W.-C., Tang, H.-J. , \& Hsueh, P.-R. (2020). Severe acute respiratory syndrome coronavirus 2 (SARS-CoV-2) and coronavirus disease2019 (COVID-19): The epidemic and the challenges. International Journal of Antimicrobial Agents, 55 (3), 1-9. https://doi.org/10.1016/j.ijantimicag.2020. 105924
[49] Liyan, S., Janette, R. H.(2007). A Conceptual Model for Understanding SelfDirected Learning in Online Environments. Journal of Interactive Online Learning, 6(1),27-40.

[50] Major, C. H. (2010). Do virtual professors dream of electric students? University faculty experiences with online distance education. Teachers College Record, 8, 2154-2208.

[51] Molden, D.C. and Dweck, C.S. (2006). Self Theories: Their Impact on Competence Motivation and Acquisition. In book: Handbook of Competence Motivation (pp.122-140).The Guilford Press.

[52] Naciri, A., Baba, M. A., Achbani, A., \& Kharbach, A. (2020). Mobile Learning in Higher Education: Unavoidable Alternative during COVID-19. Aquademia, 4(1), ep20016. https://doi.org/10.29333/aquademia/8227.

[53] Neter, J., \& Kutner, L. (1990). Applied linear statistical models. Homewood, IL: Irwin.

[54] Nguyen, N. D. H. (2020). Embracing the Growth Mindset in the Classroom. English Teaching Forum, 58(1), 31-35.

[55] Oppenheim, A.N., (1992). Questionnaire Design, Interviewing and Attitude Measurement, New York: Pinter Publishers.

[56] Panda, S., \& Mishra, S. (2007). ELearning in a mega open university: Faculty attitude, barriers and motivators. Educational Media International, 44(4), 323-338. doi: $10.1080 / 09523980701680854$

[57] Paulsen, M. P. (1995). Moderating educational computer conferences. In A. L. Berge \& M. P. Ollins (Eds.), Computermediated communication and the on-line classroom in distance education. Cresskill, NJ: Hampton Press.

[58] Perrotta, K.; Bohan, C. H. (2020). A Reflective Study of Online Faculty Teaching Experiences in Higher 
Education. Journal of Effective Teaching in Higher Education, 3(1), 50-66.

[59] Piña, A. A.(2017). An Organizational Development Framework for Assessing Readiness and Capacity for Expanding Online Education. Online Journal of Distance Learning Administration, 20(3).

[60] Preece, J., Rogers, Y. \& Sharp, S. (2002). Interaction Design: Beyond HumanComputer Interaction. New York:

[61] Reitz, H.J. (1987). Behavior in Organizations, Irwin, p.625.

[62] Richardson, D. S.; Bledsoe, R. S.; Cortez, Z. (2020). Mindset, Motivation, and Teaching Practice: Psychology Applied to Understanding Teaching and Learning in STEM Disciplines.CBE - Life Sciences Education, 19 (3) Article 46.

[63] Rigau, B. L.; Dooling-Litfin, J.; Scully, E.; Killian, C.; Fisher, G.; McManus, B.; Khetani, M. A.(2019). Building Organizational Capacity for Research in Early Intervention. ZERO TO THREE, 39 (6), 54-61.

[64] Rockwell, S. K., Schauer, J., Fritz, S. M., \& Marx, D. B. (1999). Incentives and obstacles influencing higher education faculty and administrators to teach via distance.Online Journal of Distance Learning Administration, 2(4). Retrieved from http://www.westga.edu/ distance/ ojdla/winter24/ Rockwell 24. Html

[65] Rossman, M. (1999). Successful online teaching using an asynchronous learner discussion forum. Journal of Asynchronous Learning Networks, 3(2). Retrieved from http://www.aln.org/alnweb/journal/V ol3_issue2/Rossman.htm

[66] Ryan, R. M.; Deci, E. L. (2000). Selfdetermination theory and the facilitation of intrinsic motivation, social development, and well-being. American Psychologist. 55 (1), 68-78. doi:10.1037/0003066X.55.1.68. PMID 11392867

[67] Salovey, P. (2020a, March 10). COVID-19 - Moving courses online and other significant updates. Yale University. https://covid19.yale.edu/universityannouncements-about-covid-19/covid-19moving-courses-online-and-othersignificant-updates

[68] Salovey, P.(2020b, March 14). COVID-19 Update - First confirmed Yale COVID-19 case; extending online instruction to end of spring semester; campus and staffing considerations. Yale University. https://covid19.yale.edu/universityannouncements-about-covid-19/covid-19update-first-confirmed-yale-covid-19case-extending

[69] Seaton, F.S. (2018). Empowering teachers to implement a growth mindset. Journal Educational Psychology in Practice: Theory, research, and practice in educational psychology, 34(1).

[70] Sintema, E. J. (2020). Effect of COVID-19 on the Performance of Grade 12 Students: Implications for STEM Education. Eurasia Journal of Mathematics, Science and Technology Education, 16(7), em1851. https://doi.org/ 10.29333/ejmste/7893

[71] Smith, D. A.; Coleman, D. (2018). Exploring Readiness, Motivation, and Capacity for Implementing an iPad Campus Initiative: A Rural Community College Case Study.Community College Journal of Research and Practice, 42 (7-8), 460-475.

[72] Stanton, J.M. (1998). An empirical assessment of data collection using the Internet. Personnel Psychology 51(3), 709726.

[73] Toquero, C. M. (2020). Challenges and Opportunities for Higher Education amid the COVID-19 Pandemic: The Philippine Context. Pedagogical Research, 5(4), em0063. https://doi.org/10.29333/pr/7947

[74] Turner, K. (2019). One-to-One Learning and Self-Determination Theory. International Journal of Instruction, 12 (2), $1-16$.

[75] Ulmer, L.W., Watson, L.W., \& Derby, D. (2007). Perceptions of higher education faculty members on the value of distance 
education. Quarterly Review of Distance Education, 8(1), 59-70.

[76] UNESCO, 2014a UNESCO education strategy 2014-2021. UNESCO. DirectorGeneral, 2009-2017 (Bokova, I.G.). writer of foreword [5297]. Document code: ED2014/WS/41, $61 \quad$ p. https://unesdoc.unesco.org/ark:/48223/pf0 000231288

[77] UNESCO, 2015 UNESCO and education: everyone has the right to education Document code: ED-2011/WS/30, Collation: $\quad 32 \quad$ p., $\quad$ illus. https://unesdoc.unesco. org/ark:/ 48223/ pf0000212715

[78] UNESCO, 2016 Gem report: education for people and planet: creating sustainable futures for all infographics.https://en.unesco.org/gemreport/infographics/2016-gem-reporteducation-people-and-planet-creatingsustainable-futures-all.

[79] UNESCO,2016aUNESCO. DirectorGeneral, 2009-2017(Bokova, I.G.). writer of preface [5297], ERI2017/WS/1Collation:148p. illus. https://unesdoc. unesco. org/ark:/ 48223/pf0000248073

[80] Usak, M., Masalimova, A. R., Cherdymova, E. I., \& Shaidullina, A. R. (2020). New playmaker in science education: COVID19. Journal of Baltic Science Education, 19(2), 180-185. https://doi.org/10.33225/jbse/20.19.180

[81] Wang, W.-T., \& Wang, C.-C. (2009). An empirical study of instructor adoption of web-based learning systems. Computers \& Education, 3(53), 761-774.

[82] Weiner, B. and Kukla, A. (1970). An Attributional Analysis of Achievement Motivation. Journal of Personality and Social Psychology, 15(1), 1-20.

[83] Wilder-Smith, A., Chiew, C. J., \& Lee, V. J. (2020).Can we contain the COVID-19 outbreak with the same measures as for SARS? The Lancet Infectious Diseases, Online First, 1-
6.https://doi.org/10.1016/S1473-

3099(20)30129-8

[84] Windes, D. L.; Lesht, Faye L.(2014). The Effects of Online Teaching Experience and Institution Type on Faculty Perceptions of Teaching Online. Online Journal of Distance Learning Administration, 17(1).

[85] Witmer, D.F., Colman, R.W. \& Katzman, S.L. (1999). "From paper-and-pencil to screen-and-keyboard." In Doing. Internet Research: Critical Issues and Methods for Examining the Net. S. Jones (editor). Thousand Oaks, CA: Sage.

[86] World Health Organization. (2020b). Statement on the meeting of the International Health Regulations (2005) Emergency Committee regarding the outbreak of novel coronavirus (2019nCoV). https://bit.ly/2RwodiW

[87] World Health Organization. (2020a). Naming the coronavirus disease (COVID19) and the virus that causes it. https://bit.ly/2KHu29A

[88] Wright, Z. F. (2018). Creating a Mindset for Writing. Educational Leadership, 75(7), 74-77.

[89] Xiaoying, W. and Yong, Z. (2017). Organizational Capability Model: Toward Improving Organizational Performance.Transactions of the SDPS: Journal of Integrated Design and Process Science 21 (1), 2017, 5-24 DOI 10.3233/jid-2017-0005

[90] Yang, S.; Zhou, S.; Cheng, X. (2019). Why Do College Students Continue to Use Mobile Learning? Learning Involvement and Self-Determination Theory. British Journal of Educational Technology, 50 (2), 626-637

[91] Yengin, I., Karahoca, A., \& Karahoca, D. (2011). E-learning success model for instructors' satisfaction in perpectiveof interaction and usability outcomes. Procedia Computer Science, 3, 13961403.

[92] Yu-Lee, T. R. (2002). Essentials of capacity management: John Wiley \& Sons; 2002. 